\title{
The spread of international arbitration: a survey based on views expressed in leading textbooks
}

\author{
by Anthony Connerty
}

$\mathrm{T}$ here is little doubt that there has been a spread in the use of international arbitration. As cross - border trade has increased, so cross - border disputes have increased: and, understandably, so has the use of international arbitration to deal with those disputes.

This article looks at the treatment of international arbitration in four major works, and considers the views expressed by the authors, editors and contributors on the spread of the use of international arbitration. The works considered are:

- Redfern and Hunter on International Arbitration

- International Commercial Arbitration, by Gary B Born

- Arbitration in Asia, edited by Michael Moser

- International Commercial Arbitration in New York, edited by James H Carter and John Fellas

Some of the material is taken from reviews - by the writer of this article - of three of the books.

\section{REDFERN AND HUNTER ON INTERNATIONAL ARBITRATION}

Nigel Blackaby and Constantine Partasides, with Alan Redfern and Martin Hunter

Fifth edition, 2009

Oxford University Press

849 pages

ISBN 9780199557189

(A review of this book was published in the November 2010 edition of Arbitration, the journal of the Chartered Institute of Arbitrators)

This is the fifth edition of one of the leading textbooks on international arbitration. It runs to almost 900 pages. My dog-eared copy of the first edition by Alan Redfern and for a course many years ago on international commercial arbitration run by Martin Hunter and Julian Lew at Queen Mary College in London - ran to some 460 pages.

The first edition, published in 1986, contained nine chapters: an introduction; the applicable law; arbitration clauses and submission agreements; the establishment and organisation of an arbitral tribunal; the powers, duties and jurisdiction of an arbitral tribunal; the conduct of proceedings; the award; challenge, recognition and enforcement of awards; and the role of the UN.

There are 11 chapters in the latest edition: two new chapters not included in the first edition deal with the role of the courts and with arbitration under investment treaties. The appendices have been expanded to include the Washington Convention and the ICSID Rules.

International arbitration, say the authors, is no longer "a rarefied jurisdictional exoticism... international arbitration has become the preferred method for resolving international commercial disputes around the world. There are today more users looking to the process to provide solutions to business disputes, and more lawyers counselling and arbitrating cases than ever before."

The solutions that international arbitration can provide to resolve business disputes are set out with clarity in the book, moving from an overview of international arbitration to the agreement to arbitrate and applicable laws; the establishment of the tribunal and the tribunal's powers, duties and jurisdiction; the conduct of the arbitral proceedings and the role of national courts during the arbitral proceedings. The latter chapter includes coverage of interim measures of protection.

Later chapters deal with the award, challenge to the award and the recognition and enforcement of awards: in particular enforcement under the New York Convention and under the Washington Convention 
The chapter on investment treaty arbitration takes into account "the explosion of treaty arbitration case law" and includes a section on measures of compensation under BITs. The chapter deals with "fair and equitable treatment", discriminatory treatment, expropriation and "most favoured nation" treatment.

The authors say that international arbitration "has become the principal method of resolving disputes between States, individuals and corporations in almost every aspect of international trade, commerce and investment. The established centres of arbitration report increasing activity, year on year; new arbitration centres have been set up to catch this wave of new business; States have modernised their laws so as to be seen to be 'arbitration friendly'; firms of lawyers and accountants have established dedicated groups of arbitration specialists; conferences and seminars proliferate..."

\section{INTERNATIONAL COMMERCIAL ARBITRATION}

Gary B Born

Second edition in two volumes, 2009

Wolters Kluwer

3,400 pages

ISBN 9789041127594

Gary Born is a partner in Wilmer Hale, based at their London office. He is chair of the firm's International Arbitration Practice Group.

His magisterial treatise gives what might be regarded as an American view of international arbitration - as opposed to what might be considered as the view of the English lawyers Alan Redfern and Martin Hunter.

But the broad picture is similar - as might be expected from three common law lawyers: "The preferences which businesses have demonstrated for arbitration, as a means for resolving their international disputes, has become even more pronounced in the past several decades as international trade and investment have burgeoned. As international commerce has expanded and become more complex, so too has its primary dispute resolution method - international arbitration."

Volume I comprises 13 chapters. Part I of volume I deals with international commercial arbitration agreements: an overview; the legal framework for international arbitration agreements; the separability presumption; choice of law governing the arbitration agreement; arbitration agreements: formation, validity and legality; competencecompetence; effect and enforcement of arbitration agreements; interpretation of agreements; and parties the chapter includes a consideration of the non-signatories problem.

The three chapters of part II of volume I deal with the legal framework for international arbitration proceedings; the selection, challenge and replacement of arbitrators; the rights and duties of international arbitrators; and the selection of an arbitral seat.

In volume II, chapters 14 to 20 continue with the part II scheme of the procedural stage of international arbitration: procedures; disclosure and discovery; provisional measures; consolidation, joinder and intervention; choice of substantive law; confidentiality; and legal representation and professional conduct ("international arbitration dwells in an ethical no-man's land”).

Part III moves on to awards: the legal framework of awards; form and contents; correction, interpretation and supplementation; annulment; and recognition and enforcement.

The final chapter includes a consideration of stare decisis: "the role of precedent - both judicial and arbitral - in international arbitration is significant, albeit still evolving." The appendices include indexes of cases and arbitral awards, as well as a subject index.

Gary Born concludes that the treatments of international commercial arbitration in different legal systems "are not diverse, unrelated phenomena, but rather form a common corpus of international arbitration law which has global application.... there is a common body of international arbitration law."

\section{ARBITRATION IN ASIA}

Edited by Michael J Moser

Second edition September 2008; updated December 2010 Juris Publishing, Huntington, New York, USA

782 pages

ISBN 9781933833200

(A review of this book will be published in Arbitration, the journal of the Chartered Institute of Arbitrators).

The survey thus far has looked at what might be regarded as an Anglo - American / common law view of international commercial arbitration. We now move to a view that gives an Asian perspective.

Originally published in 2008, the second edition of Arbitration in Asia was updated by a release in December 2010: the next release is expected to be at the end of 2011.

In his Foreword to this looseleaf volume, Philip L Y Yang, President of the Asia Pacific Regional Arbitration Group, says that Asia has experienced dramatic growth in the use of international arbitration in the past two decadesa development that coincides with an extraordinary growth in cross-border trade and investment in the area. It is in those circumstances, he says, that practitioners are faced with the problem of identifying an appropriate arbitral "seat" and an appropriate set of arbitral rules when negotiating and drafting contracts.

The areas in Asia considered are set out in seventeen sections: Japan, Korea, Mongolia, China, Hong Kong, Taiwan, Philippines, Vietnam, Laos, Cambodia, Thailand, 
Myanmar, Singapore, Malaysia, Indonesia, India and finally Australia and New Zealand.

Each section follows a broadly similar pattern: the legislation of the country in question, arbitration agreements, arbitral institutions, arbitral procedure, awards, recognition and enforcement of awards and judicial assistance and intervention.

By way of illustration, the sections on Hong Kong, China, Singapore and India are now considered.

\section{Hong Kong}

The Hong Kong contributors are Michael Moser and Christopher To.

Michael Moser is a highly experienced international arbitrator who has acted as counsel and arbitrator in arbitrations under the Rules of the major arbitral institutions. A resident in China for over 30 years, he was the first foreigner to be appointed as an arbitrator in China.

Christopher To was for many years the Secretary General of the Hong Kong International Arbitration Centre and is a panel member of various arbitral institutions.

The contributors say in their introduction that Hong Kong has a modern UNCITRAL - based arbitration law, an independent judiciary, an English law based legal system "and a large number of highly skilled local professionals".

Formerly a dependent territory of the United Kingdom, sovereignty of Hong Kong was resumed by the People's Republic of China in July 1997. Under the terms of China's resumption of sovereignty, Hong Kong was permitted to retain its own legal system distinct from that of China, and "although Hong Kong is today a part of the PRC, its arbitration law and institutions remain separate from those of the mainland."

The contributors set out the relevant legislation applicable in Hong Kong, the distinction between international and domestic arbitration, the requirements of an arbitration agreement and the rules applicable to the conduct of an international arbitration. Hong Kong's international arbitration regime is based on the UNCITRAL Model Law, which therefore governs judicial assistance and intervention in matters such as interim measures of protection.

In relation to the enforcement of international arbitration awards, China extended its membership in the New York Convention to Hong Kong following the resumption of sovereignty in 1997.

\section{China}

The contributors to the section on the People's Republic of China are the General Editor Michael Moser and Wang Wenying. Dr Wang has held posts in the China Council for the Promotion of International Trade (CCPIT). She has served as arbitrator in various domestic and international arbitration panels.

The section covers the relevant legislation - the principal legislation being the Arbitration Law of 1995 and the major arbitral institutions dealing with "foreign -related" arbitration: CIETAC and its sister institution, the China Maritime Arbitration Commission (CMAC). Discussions on arbitration agreements (including submission agreements) and the provisions relating to arbitrators and arbitral tribunals are followed by a consideration of arbitral procedure. The latter includes preliminary meetings, interim relief and hearings.

The section goes on to look at the recognition and enforcement of awards, including the enforcement of CIETAC and CMAC awards abroad. China acceded to the New York Convention in 1987. According to CIETAC, Chinese arbitral awards have been enforced under the Convention in the UK, the US, Canada, France, Germany, New Zealand, Japan, Italy and Singapore.

\section{Singapore}

The contributors are Michael Hwang SC, Andrew Chan and Ramesh Selvaraj. Michael Hwang is an international arbitrator who has held various posts in major arbitration organisations such as the ICC, ICCA and LCIA. Andrew Chan is a partner in the Singapore law firm of Allen \& Gledhill. He has acted as counsel and arbitrator in arbitration matters relating to Singapore. Ramesh Selvaraj is a senior associate at Allen \& Gledhill.

An overview of Singapore's legal system and laws is followed by a description of the dual track system for international arbitration and domestic arbitration. Arbitration agreements are to be in writing, but may be incorporated by reference - and there is the possibility of an option to arbitrate constituting a valid agreement to arbitrate.

The contributors consider the position in Singapore in relation to arbitrability, the rights of third parties, the separability of arbitration clauses and confidentiality. The section then looks at arbitrators and the arbitral tribunal: appointment, qualifications, impartiality and independence. Arbitral procedure, the type, form and contents of arbitration awards and recourse against awards are considered in detail, as is the position in relation to enforcement of awards made in Singapore.

Dealing with judicial assistance and intervention, the contributors say that the Singapore courts "have increasingly given recognition to the move to promote Singapore as an international arbitration centre". Singapore's determination to be recognised as one of the area's major centres is illustrated by the final part of this section which gives practical information on arbitration in Singapore - including information on the Singapore 
International Arbitration Centre (SIAC) and on Maxwell Chambers "the world's first integrated dispute resolution centre... which brings together under one roof the SIAC, the Singapore Chamber of Maritime Arbitration, the International Centre for Dispute Resolution Singapore, the Court of Arbitration of the ICC, the Permanent Court of Arbitration, the World Intellectual Property Organisation and the Singapore Institute of Arbitrators."

\section{India}

The contributor is the well-known Indian arbitrator Fali S Nariman, Honorary President of ICCA and former Vice - Chairman of the ICC International Court of Arbitration. In his Introduction to the section, Mr Nariman takes a frank look at the history of arbitration in India: "Although Indian Law favours dispute -resolution by arbitration, Indian sentiment abhors the finality attaching to arbitral awards!"

He then sets out the relevant legislation, deals with arbitration agreements, arbitrators and the arbitral tribunal, and moves on to arbitration procedure: place, time limits, evidence and deposits as an advance on costs. The final part of the section covers awards; judicial assistance and intervention; and recognition and enforcement: in his introduction Mr Nariman states that "there is no foreigner - bias in our legal system nor amongst our judges. The foreigner loses or wins as often as the local.”

Editor Michael Moser in his introduction makes the point that, whereas some years ago Asia would have received scant mention in the list of the top 10 busiest international arbitration bodies, "the picture today is quite different”. In 1985 CIETAC - the China International Economic and Trade Arbitration Commission - handled 37 cases: "ten years later the number topped 900. In 1985 the number of cases referred to the Hong Kong International Arbitration Centre ('HKIAC') was 9. Today the number is approaching 500.”

\section{INTERNATIONAL COMMERCIAL ARBITRATION IN NEW YORK}

James H Carter and John Fellas

Oxford University Press, 2010

672 pages

ISBN 9780195357626

(A review by the writer was published in the November 26, 2010 edition of New Law Journal).

This survey now turns to a text which deals with international arbitration in a specific city: New York. The significance of the Carter/Fellas book for the purposes of the survey lies in the opinions expressed on international arbitration in a global context. Whilst concentrating on international commercial arbitration in New York, the book is of general application to international commercial arbitration worldwide.
This is a significant book from two experienced international arbitrators, with sections contributed by specialists in this complex field.

As Winston Churchill said of democracy - it may not be perfect but so far no one has come up with a better idea so distinguished international arbitrator Gerald Aksen points out in his foreword that international arbitration "is popular because no one has yet figured out a better method of settling disputes in the context of international commercial relations with a modicum of confidentiality and an effective means of enforcing the resultant decision".

Mr Aksen adds that the book is relevant "whether you are in London, New York or Paris."

The editors, two leading members of the New York Bar, invited colleagues to contribute 13 separate "legal monologues." Much of what is contained in the 13 chapters is of specific relevance to New York arbitration.

For example, chapters on the law applicable to international arbitration in New York; the impact of US litigation; drafting considerations for clauses designating New York as the place of arbitration; the application of New York law to contracts; jurisdiction: Courts v Arbitrators; and challenging and enforcing international arbitral awards in New York courts.

Other chapters deal with areas of general application. For example, the chapter contributed by James Carter covers the topic of selection of arbitrators: rules on tribunal formation under some of the leading institutions such as the AAA/ICDR and the ICC; neutrality of partyappointed arbitrators; strategy in selecting members of a tripartite tribunal; where to find arbitrators; the selection process; conflict checks; and the challenge and replacement of arbitrators.

Again of general application and of great significance is the chapter by John Fellas on enforcing arbitration agreements. That chapter includes a look at the New York Convention, described as "the cornerstone of current international commercial arbitration". Gerald Aksen regards the promulgation in New York of the 1958 UN Convention on the Recognition and Enforcement of Foreign Arbitral Awards as ushering in "the Golden Age of International Arbitration".

Similarly, the chapter dealing with the difficult topic of damages in international arbitration is of importance on a global basis. That chapter includes sections on commercial damages for breach of contract; expectation damages; liquidated damages and penalties; damages for anticipated future profits; calculation of interest; and awards of costs.

The chapters on preliminary relief and discovery are of significance wherever an arbitration takes place. Of narrower application but of increasing importance is the enforcement of awards involving foreign sovereigns. 
Of particular interest is the chapter on class action arbitration. Even in the United States this is a recent phenomenon. But will the use of such arbitrations spread beyond the US? In their introduction to the book, the editors suggest that the "Americanization" of international arbitration has spawned class arbitration in which a claimant brings claims on behalf of himself and also on behalf of others.

The 13 chapters are followed by some useful appendices. These include the New York Convention; the Federal Arbitration Act; the AAA/ICDR Arbitration and Mediation Rules; the ICC Arbitration Rules; and the AAA/ABA Code of Ethics for Arbitrators in Commercial Disputes.

James Carter (a partner in the New York office of Sullivan \& Cromwell LLP at the time of writing the book) is Global Co-Chair, International Arbitration and CrossBorder Dispute Resolution, at Dewey \& LeBoeuf LLP, New York. John Fellas is a partner in the New York office of Hughes Hubbard \& Reed LLP.

The Carter / Fellas book seems likely to become one of the significant publications in the field of international commercial arbitration: a field which is of increasing importance as world trade increases - and as the number of disputes involving cross-border contracts is increasing.

\section{WHAT HAS THIS BRIEF SURVEY SHOWN ABOUT THE USE OF INTERNATIONAL ARBITRATION?}

Four major texts have been considered. The authors, editors and contributors - drawn from around the world are in little doubt: the use of international arbitration as a means of resolving cross-border disputes is spreading and is likely to continue doing so.

\section{Why?}

The prime reason is the increase in international trade and commerce. Linked to that is the fact that international arbitration is regarded as a successful and competent mechanism for handling complex international commercial disputes: and, as Gary Born notes, there is "a common corpus of international arbitration law which has global application." Underlying those reasons is the fact the New York Convention provides an enforcement process available in most of the world's trading nations.

Further, as Gerald Aksen points out, no one has yet figured out a better method of settling international disputes.

\section{Anthony Connerty}

The author is a barrister in practice at Lamb Chambers, Temple, London. He acts as Counsel and Arbitrator in major international commercial arbitrations in multi-million US dollar claims: AAA/ICDR, International Chamber of Commerce (ICC), London Court of International Arbitration (LCIA), Arbitration Institute of the Stockholm Chamber of Commerce (SCC), London Metal Exchange (LME) and ad hoc arbitration (including arbitration under the UNCITRAL Rules). He is a CEDR-Accredited mediator and an IMI Certified mediator, and acts as counsel and mediator in international mediations.

He is a member of various international arbitration and mediation panels including CIETAC, HKIAC, SIAC, Dubai, Cairo and Abu Dhabi, and is a member of the Arbitration Panel of the Hong Kong International Arbitration Centre's Lehman Brothers Mediation and Arbitration Scheme. 